\title{
Interference of Bilirubin in Serum Creatinine Value Measurement by Jaffe's Kinetic Method
}

\author{
1Jay Prakash Sah, ${ }^{1}$ Suresh Jaiswal \\ ${ }^{1}$ School of Health and Allied Sciences, Pokhara University, Kaski, Nepal
}

\begin{abstract}
The Serum creatinine measurement by Jaffe kinetic method in Icteric patients is a major problem due to negative interference of bilirubin. Bilirubin is the major chromogen present in serum which decreases the optical density during creatinine estimation due to its similar absorbance with colored incubation product of creatinine with Jaffe's reagent. The objective of this study was to minimize the bilirubin interference in serum creatinine estimation in Jaffe's Kinetic Method by converting bilirubin to biliverdin in pre-incubation state with oxidizing reagents, $20 \%$ aqueous $\mathrm{NaOH}$ solution. Icteric Patients of inwards and outpatient department of Manmohan Memorial Hospital, Kathmandu were selected for cross-sectional study. The manual procedure, Jaffe Kinetic method for serum creatinine estimation was performed using $20 \% \mathrm{NaOH}$ solution as an oxidizing agent to study the bilirubin interference. The increased serum true creatinine value was found by pre-incubation of serum with $20 \% \mathrm{NaOH}$ solution than without its preincubation in Jaffe's reagent. The mean serum true creatinine value obtained by pre-incubation with $20 \% \mathrm{NaOH}$ solution was found to be $1.31 \pm 0.67 \mathrm{mg} / \mathrm{dl}$ which was significantly higher by student's two tailed t test $(p<0.01)$ than serum interference creatinine value obtained without pre- incubation (Mean serum creatinine- $1.048 \pm 0.68 \mathrm{mg} / \mathrm{dl}$ ). Serum true creatinine value obtained by Jaffe's method with pre-incubation with $20 \% \mathrm{NaOH}$ solution was increased. Hence bilirubin is the dominant interfering substance present in the serum for true creatinine value estimation by Jaffe Method and $20 \% \mathrm{NaOH}$ solution can solve this problem by acting as oxidizing agent that convert bilirubin to biliverdin before Jaffe's reaction.
\end{abstract}

Key words: Creatinine, True Creatinine, Bilirubin, Biliverdin

Corresponding address: Jay Prakash Sah, School of Health and Allied Sciences, Pokhara University, Kaski, Nepal. E-mail: shahjayprakash@yahoo.com

\section{INTRODUCTION}

Creatinine is the break down and waste product of high energy phosphate compound, creatine phosphate present in muscle. And its synthesis in the body is spontaneous process. The amount of creatinine produced per day depends upon the muscle mass, age, sex, diet and exercise. It is not stored in the body. It is excreted in urine which is specific parameter for measurement of GFR. Decreased Creatinine clearance is the major finding of kidney impairment which is seen in complicated stage of severe Jaundice. ${ }^{1}$

The most commonly used method for serum creatinine estimation in clinical laboratory is Jaffe's kinetic method. This method is non-specific for serum creatinine estimation because Bilirubin is a major, specific chromogen that reacts with Jaffe's reagent, picric acid and produce similar color thereby giving false negative value of creatinine. ${ }^{2-8,9}$ Only $80 \%$ of the color developed during performing test is due to serum creatinine. Other nonspecific chromogens that react with picric acid are proteins, ketone bodies, pyruvate, glucose, ascorbate etc. which are responsible for false positive value of creatinine. ${ }^{9}$

The first attempt to decrease bilirubin interference in serum creatinine estimation by Jaffe's method were the absorption of creatinine into hydrated aluminum silicate (Fuller's earth, Lloyd's reagent), Ion exchange resins, selective absorption, solvent extraction method etc. but these were not applicable due to high cost in all laboratory. ${ }^{10}$ Then, it was suggested that interference could be decreased by oxidizing interfering substances to the compounds which could not react with Jaffe's reagent. For this purpose, cerium sulfate was used but this was not applicable for all interfering substances. ${ }^{9}$ Another approach to eliminate the interferences in the Jaffe reaction is acid blanking. ${ }^{10}$ But this technique also gives many error due to different interfering substances in serum. An important approach to minimize bilirubin interference is to oxidize bilirubin to biliverdin using $\mathrm{NaOH} .{ }^{6}$ Sodium hydroxide has oxidizing property and is readily available..$^{13}$ Serum Creatinine value in icteric serum sample with pre incubation with $20 \% \mathrm{NaOH}$ before Jaffe's reagent addition (true creatinine) was lower than without pre-incubation with it in researches done in this regard by other researchers. ${ }^{8,9-13}$ This study was carried out to find out the activity of $\mathrm{NaOH}$ in its $20 \%$ concentration to decrease bilirubin interference in serum creatinine estimation by Jaffe's Kinetic method for the convenience of all the types of laboratories use.

\section{MATERIAL AND METHODS}

A descriptive, cross sectional study was carried out in Department of Pathology, Manmohan Memorial Community Hospital, Lekhnathmarg, Thamel, Kathmandu in the duration of 6 months from June 2010 to November 2010. Some clinical samples with high bilirubin level were also received from Bir Hospital, Kathmandu, Nepal. Subjects were taken from ward and outpatient department of Manmohan Mamorial Hospital, Lekhanathmarg, Kathmandu. 
The patients suffering from Jaundice were taken as study group and the total 71 blood samples were collected randomly and separated the serum for the assay. The patient who are unconscious and refuse to give consent for blood examination were excluded from this study.

The Total and Direct bilirubin level in the serum of subjects was determined by Modified Jendrassik/ Grof Method.8 Serum creatinine estimation was done by Jaffe's Kinetic Method. ${ }^{5}$ The data obtained were statically analyzed by Microsoft Excel and statistical package SPSS version 16.0. The level of significant is considered if $p$ values were less than 0.05 , i.e. at $5 \%$ level.

\section{RESULTS}

The total 71 serum samples of Jaundice Patients were taken for this study. The mean concentration of bilirubin and creatinine was found to be 5.728 and 1.048 respectively (Table1). The creatinine values of without pre-incubation and with pre-incubation with $\mathrm{NaOH}$ were 1.048 and 1.031 respectively. The mean difference of creatinine (without pre incubation) and true creatinine (pre incubation with $\mathrm{NaOH}$ ) was found to be statistically significant $(p<0.05)$.

Table 1: Mean, median, S.D, minimum value of bilirubin and creatinine of total (71) samples.

\begin{tabular}{|c|c|c|c|c|}
\hline Strategy & $\begin{array}{c}\text { Bilirubin } \\
(\mathrm{mg} / \mathrm{dl})\end{array}$ & $\begin{array}{c}\text { Interference } \\
\text { Creatinine } \\
(\mathrm{mg} / \mathrm{dl})\end{array}$ & $\begin{array}{c}\text { True } \\
\text { creatinine } \\
(\mathrm{mg} / \mathrm{dl})\end{array}$ & \multirow{2}{*}{ t-test (1-tail) } \\
\cline { 1 - 3 } Mean & 5.73 & $\begin{array}{c}1.048 \pm \\
0.68\end{array}$ & $1.31 \pm 0.673$ & \multirow{2}{*}{$\mathrm{P}=0.00000493$} \\
\hline Median & 2.80 & 0.90 & 1.10 & \\
\cline { 1 - 3 } Minimum & 0.70 & 0.00 & 0.60 & \\
\cline { 1 - 3 } Maximum & 27.10 & 3.90 & 4.10 & \\
\hline $\mathrm{P}=$ student's t-test done between Interference creatinine and
\end{tabular}
true creatinine

This shows (Table 1) that Creatinine value obtained by pre incubation with $20 \% \mathrm{NaOH}$ solution is lower than without pre incubation in icteric sample. And a large difference in serum creatinine value is at bilirubin above $20.0 \mathrm{mg} / \mathrm{dl}$

Table 2: Correlation between Different bilirubin concentrations and creatinine values

\begin{tabular}{|c|c|c|c|c|}
\hline $\begin{array}{c}\text { Bilirubin } \\
\text { [mg/dl] }\end{array}$ & Strategy & $\begin{array}{c}\text { Interference } \\
\text { Creatinine } \\
\text { (mg/dl) }\end{array}$ & $\begin{array}{c}\text { True } \\
\text { creatinine } \\
\text { ( mg/dl) }\end{array}$ & t-test(1-tail) \\
\hline \multirow{2}{*}{$<1.0$} & Number & 22 & 22 & \multirow{2}{*}{$\mathrm{P}=0.0000702$} \\
\hline & Mean & $0.87 \pm 0.22$ & $0.98 \pm 0.24$ & \\
\hline \multirow{2}{*}{$1.0-5.0$} & Number & 24 & 24 & \multirow{2}{*}{$\mathrm{P}=3.55 \mathrm{E}-07$} \\
\hline & Mean & $1.192 \pm 0.75$ & $1.37 \pm 0.76$ & \\
\hline \multirow[b]{2}{*}{$5.0-10.0$} & Number & 12 & 12 & \multirow[b]{2}{*}{$\mathrm{P}=5.96 \mathrm{E}-07$} \\
\hline & Mean & $1.16 \pm 0.56$ & $\begin{array}{l}1.45 \pm \\
0.54\end{array}$ & \\
\hline \multirow[b]{2}{*}{$10.0-15.0$} & Number & 5 & 5 & \multirow[b]{2}{*}{$\mathrm{P}=0.00159$} \\
\hline & Mean & $1.74 \pm 1.20$ & $\begin{array}{l}2.16 \pm \\
1.14 \\
\end{array}$ & \\
\hline \multirow{2}{*}{$15.0-20.0$} & Number & 5 & 5 & \multirow{2}{*}{$\mathrm{P}=0.00138$} \\
\hline & Mean & $1.1 \pm 0.73$ & $1.63 \pm 0.71$ & \\
\hline \multirow{2}{*}{$>20.0$} & Number & 3 & 3 & \multirow{2}{*}{$\mathrm{P}=0.00192$} \\
\hline & Mean & 0.00 & $1.00 \pm 0.29$ & \\
\hline
\end{tabular}

The different concentrations of bilirubin interference in creatinine estimation are different (Table 2). The serum creatinine values were increased in different extent after pre incubation with $20 \% \mathrm{NaOH}$ solution. For bilirubin level less than $1 \mathrm{mg} / \mathrm{dl}$, the true creatinine value of pre incubation with $20 \% \mathrm{NaOH}$ solution slightly increased than creatinine obtained without pre incubation with $20 \% \mathrm{NaOH}$ solution and the data were statistically significant i.e. $(\mathrm{P}<0.01)$.

For bilirubin level of $1.0-10.0 \mathrm{mg} / \mathrm{dl}$, the true creatinine value was slightly increased which was not satisfied by t test. For bilirubin level of $10.0-15.0 \mathrm{mg} / \mathrm{dl}$, the true creatinine values were mildly increased and for bilirubin level of 15.0-20.0 $\mathrm{mg} / \mathrm{dl}$, the true creatinine values were moderately increased. And rest of samples i.e bilirubin level greater than $20.0 \mathrm{mg} /$ $\mathrm{dl}$, the true creatinine values were found to be significantly increased.

\section{DISCUSSION}

In this study, the great significant interference of bilirubin with serum creatinine estimation by Jaffe Kinetic method which may be due to same color of Jaffe's reagent and bilirubin or similar absorbance of bilirubin and creatinine. The creatinine value obtained by pre incubation with $20 \%$ $\mathrm{NaOH}$ solution (i.e. true creatinine) was found to be increased than creatinine obtained without pre incubation (Interference creatinine) (Table 1). Similar findings were reported by other Researchers. ${ }^{8,9,11,12,13}$ Vaishya et al., observed that the little variation in creatinine estimation for normal bilirubin concentration, and for bilirubin concentration $5.0-20.0 \mathrm{mg} / \mathrm{dl}$, there was great interference of bilirubin in serum creatinine estimation which may be due to nearly similar sample size taken or similar concentration of $\mathrm{NaOH}$ solution used. ${ }^{14}$ The serum true creatinine values were increased in greater extent with increased bilirubin concentration. And Bilirubin concentration above $25.0 \mathrm{mg} / \mathrm{dl}$, serum true creatinine value after pre incubation with $20 \%$ aqueous $\mathrm{NaOH}$ solution were found to be significantly increased which was also correlated by other researchers. ${ }^{13,16}$

On evaluating serum true creatinine concentration, Variable result was found for different concentrations of bilirubin. For bilirubin concentration $<1 \mathrm{mg} / \mathrm{dl}$, there was just little variation in serum true creatinine mean value (Table 2). This may be due to light yellow color of serum due to low concentration of bilirubin present. Similar findings were shown by Vaishya et al. ${ }^{16}$ and the $\mathrm{P}$ value also showed significant $(\mathrm{P}<0.01)$ for this group which is not similar to other previous research, this may be due to unequal sample size taken.

For bilirubin concentration $1-5 \mathrm{mg} / \mathrm{dl}$ and $5-10 \mathrm{mg} / \mathrm{dl}$, there was mildly increase in serum true creatinine value. Similarly for bilirubin concentration of $10-20 \mathrm{mg} / \mathrm{dl}$ (in two categories $10-15$ and $15-20 \mathrm{mg} / \mathrm{dl}$ ), there were moderately increase in serum true creatinine value (Table 2 ), which was similarly correlated with other Researchers. ${ }^{11,12,14}$ This type of findings were due to dark yellow color of serum containing high bilirubin concentration. The bilirubin concentration $>20 \mathrm{mg} / \mathrm{dl}$ (Table 2), for, serum true creatinine value (i.e Pre incubation with $\mathrm{NaOH}$ ) was found to be increased significantly which was not satisfied by Vaishya et al., but this finding was satisfied by other researchers. ${ }^{4,14}$ 


\section{CONCLUSION}

From this study, it was found that different concentration of bilirubin interfered in creatinine value measurement in different way i.e. the interfering effect of bilirubin increased with its concentration. The significant increase in serum true creatinine (obtained by pre incubation with $\mathrm{NaOH})$ is only found for bilirubin concentration $>20 \mathrm{mg} / \mathrm{dl}(P<0.01)$. Serum creatinine value obtained by pre incubation with $20 \%$ aqueous $\mathrm{NaOH}$ solution is increased significantly which is due to oxidizing property of aqueous $\mathrm{NaOH}$ solution. $\mathrm{NaOH}$ oxidizes bilimbin to biliverdin thereby causing decrease in optical absorption. Therefore, $\mathrm{NaOH}$ solution is an excellent oxidizing agent for removal of bilinubin interference for serum true creatinine estimation by Jaffe's method.

\section{ACKNOWLEDGEMENT}

We express our sincere thanks to Mr. Rajendra Pandey; Founder and Director of Manmohan Memorial Hospital, Lekhnathmarg, Thamel, Kathmandu who provided a valuable support by giving permission to perform the tests for research study. We would also like to express our sincere thanks to Mr: Rajan Dahal, Siddartha Shankar Chaudhary and all the known and unknown professionals of Manmohan Memorial Hospital for their contribution to complete the research.

\section{REFERENCES}

1. Burtis CA, Ashwood ER, Bruns DE, Sawyer BG. TIETZ Text book of Clinical Chemistry. 3rd Edition. Saunders- An inptint of Elsevier inc., St. Louis, Missouri (USA) 1999; 1241-45.

2. Akriviadis E, Botla R, Briggs W, Han S, Reynolds T, Shakil O. Pentoxifylline improves short-term survival in severe acute alcoholic hepatitis: a double-blind, placebo-controlled trial. Gastroenterology 2000; 119(6):1637-48.

3. Blijenberg BG, Zwang L. Serum Creatinine and DuPont Dimension: Possible Improvements. Eur. J. Clin.chem,clin. Biochem. 1993; $31: 147-15$.

4. Schoenmarkers CHH, Kuller T. Automated Enzymatic Methods for Creatinine Measurement with SpecialAttention to Bilirubin Interference. Eur. J. Clin. Chem., Clin. Biochem. 1993; 31(12):861-868.

5. Maizy F. CREATININE Kinetic method, Reagent for Quantitative determination of Creatinine in human serum, plasma or urine. BIOLABO SA. 2008; 12/09:89-107.

6. Davis CL, Gonwa TA, Wilkinson AH. Pathophysiology of Renal Disease associated with Liver disorders: Implications for liver transplantation. Liver Transpl. 2002 Feb; 8(2):91-109.

7. Ginès A, Escorsell A, Ginès P. Incidence, Predictive factors, and Prognosis of the Hepatorenal Syndrome in Cirrhosis with Ascites. Gastroenterology 1993; 105(1):229-36.

8. QRajs G, Myer M. Oxidation Markedly Reduces Bilirubin Interference in the Jaffe Creatinine Assay. Clinical Chemistry 1992; $38(12): 2411-13$.

9. Jacobs MR, Lumsden HJ. Effects of interferents on the kinetic Jaffe reaction and an enzymatic colorimetric test for serum creatinine concentration: Determination in Cats, Cows, Dogs, and Horses. Can J Vet Res. 1991; 55:150-154.

10. Kilo J, Margreiter EJ, Ruthmann E. Slightly elevated Serum Creatinine Predicts Renal Failure Requiring Hemofiltration after Cardiac Surgery. The Heart Surgery Forum 2004; 1117:13-24.

11. Knapp ML, Hadid O. Investigations into the negative interference by jaundiced Plasma in Kinetic Jaffe's Methods for Plasma Creatinine Estimations. Ann Clin. Biochem. 1987; 24:85-97.

12. Knapp ML, Myane PD. Development of an automatic kinetic Jaffe method designed to minimize bilirubin interference in plasma creatinine assays.Clin. Chem. Acta. 1987; 168:239-46.

13. Leary O, Pembroke A, Duggan PF. A Simplified Procedure for Eliminating the Negative Interference of Bilirubin in the Jaffe Reaction for Creatinine. Clin. Chem. 1992; 38:1749-1751.

14. Vaishya R, Arora S, Singh B. Modification of Jaffe's Kinetic Method decreases Bilirubin Interference: A Preliminary Report. Clin. biochem $2005 ; 32: 64-69$. 
